\begin{tabular}{|c|c|}
\hline Postprint Version & 1.0 \\
\hline Journal website & http://content.apa.org/journals/fam/19/2/217 \\
\hline Pubmed link & $\begin{array}{l}\text { http://www.ncbi.nlm.nih.gov/entrez/query.fcgi?cmd=Retrieve\&db=pubmed } \\
\text { \&dopt=Abstract\&list uids=15982097\&query } \mathrm{hl}=8 \text { \&itool=pubmed DocSu } \\
\mathrm{m}\end{array}$ \\
\hline DOI & $10.1037 / 0893-3200.19 .2 .217$ \\
\hline
\end{tabular}

Anja J. E. Dirkzwager, Inge Bramsen, and Henk M. van der Ploeg, Department of Medical Psychology, VU University Medical Center, Amsterdam, the Netherlands; Herman Ade`r, Department of Clinical Epidemiology and Biostatistics, VU University Medical Center, Amsterdam, the Netherlands.

Correspondence concerning this article should be addressed to Anja J. E. Dirkzwager, Department of Medical Psychology, VU University Medical Center, Van Der Boechorststraat 7, 1081 BT Amsterdam, the Netherlands. E-mail: anja_dirkzwager@hotmail.com

\title{
Secondary Traumatization in Partners and Parents of Dutch Peacekeeping Soldiers
}

\author{
ANJA J. E. DirkZWAger, Inge Bramsen, HERMAn AdE`R, AND HENK M. VAN DER PlOEg \\ VU UNIVERSITY MEDICAL CENTER
}

This study examines secondary traumatization among 708 partners and 332 parents of Dutch peacekeepers (i.e., personnel who participated in military actions implemented by international organizations such as the United Nations). Partners or parents of peacekeepers with 4 levels of posttraumatic stress symptoms were compared on posttraumatic stress, health problems, the quality of the marital relationship, and social support. In comparison with partners of peacekeepers without posttraumatic stress disorder (PTSD) symptoms, partners of peacekeepers with PTSD symptoms reported more sleeping and somatic problems, reported more negative social support, and judged the marital relationship as less favorable. No

significant differences were found for parents. Thus, peacekeepers' stress reactions were related to various problems of their partners. A systemic approach to the treatment of persons with PTSD appears appropriate.

Figley (1998) has discussed the term secondary traumatic stress as "the natural consequent behaviors and emotions resulting from knowledge about a stressful event experienced by a significant other" (p. 7). The term refers to the stress that results from caring for, helping, or wanting to help a traumatized person. An accumulation of secondary traumatic stress can lead to emotional exhaustion and emotional burnout, the so-called secondary traumatic stress disorder.

Particular symptoms of posttraumatic stress disorder (PTSD), such as feelings of detachment or estrangement from others, restricted affect, irritability, and outbursts of anger, may lead to a deterioration in interpersonal relationships. In addition, it has been shown that compared with combat veterans without PTSD, veterans with PTSD reported greater hostility, more problems with intimacy and sociability, more family problems, more problems with self-disclosure and expressiveness to their partners, and more physical aggression (Beckham, Roodman, et al., 1996; Carroll, Rueger, Foy, \& Donahoe, 1985; Roberts, Gearing, Robinowitz, Dolan, \& Patterson, 1982). In dealing with such problems, family members of veterans with PTSD may experience a burden of care and may themselves develop psychological symptoms (Beckham, Lytle, \& Feldman, 1996; Figley, 1998; Jordan et al., 1992; Solomon et al., 1992). Thus, the impact of a traumatic event is not limited to the traumatized person but can also negatively affect the family surrounding and caring for this person.

Little is known about the factors that bring about secondary traumatization, and knowledge with respect to the possible transmission of PTSD symptoms to family members is largely based on clinical 
observations (Figley, 1998). Maloney (1988), for instance, showed that some female partners of Vietnam veterans may be affected by the same stimuli that appeared to trigger flashback responses in their husbands. For instance, in response to the sound of a helicopter or sudden noises, they felt panicked for a short period. Some wives also reported that they had dreams of Vietnam. The author suggested that these partners might identify with their husbands to such an extent that they have authentically internalized the veterans' stressor imagery. Figley (1998) has discussed the trauma transmission model. This model suggests that members of systems, in an effort to generate an understanding about the member who is experiencing traumatic stress, are motivated to express empathy toward the troubled member. In the resulting process, the system member experiences emotions that are strikingly similar to those of the victim. This includes visual images, sleeping problems, depression, and other symptoms that are a direct result of visualizing the victim's traumatic experiences, exposure to the symptoms of the victim, or both.

Earlier studies on secondary traumatization in families of combat veterans have focused on partners of Israeli veterans, partners of Vietnam War veterans, and partners of Dutch veterans who participated in World War II, the former Dutch East Indies, and Korea (Bramsen, Klaaren- beek, \& Van der Ploeg, 1995; Jordan et al., 1992; Riggs, Byrne, Weathers, \& Litz, 1998; Solomon et al., 1992). These studies consistently demonstrated that partners of combat veterans with PTSD reported more problems than partners of veterans without PTSD. Compared with partners of veterans without PTSD, partners of veterans with PTSD showed increased levels of health-related problems, such as psychiatric symptoms and PTSD symptoms, and reported more marital and family adjustment problems and more problems in social relationships. Partners of veterans with PTSD also reported lower levels of happiness and life satisfaction. A recent study among 444 Dutch couples of World War II survivors demonstrated that the most important predictors of current PTSD symptoms were the number of war events reported by the subject and the current level of PTSD symptoms of his or her spouse (Bramsen, Van der Ploeg, \& Twisk, 2002).

The number of peacekeeping operations has increased substantially since 1990. Peacekeepers are defined as personnel who are participating in military actions implemented by international organizations such as the United Nations, the North Atlantic Treaty Organization (NATO), and the Organization for Security and Cooperation in Europe (OVSE). Over time, different types of peacekeeping operations have developed, including for example, United Nations presence, observer missions, peacekeeping missions, and peace enforcement operations, and these interventions are characterized by varying degrees of the use of military force (Egge, Mortensen, \& Weisaeth, 1996). For instance, peacekeeping missions refer to interventions with military units following agreement between the conflicting parties. In contrast to more traditional combat soldiers, peacekeepers have to remain impartial, are less likely to carry arms than the conflicting parties, and the use of their weapons is severely restricted. In addition, no clear "enemy" is present; hostilities aimed at the peacekeepers may come from all conflicting parties. Peace enforcement operations refer to the use of military force to stop an aggressor, for example, Operation Desert Storm. The present study includes peacekeepers from different types of peacekeeping operations.

Although peacekeeping operations are frequently associated with a lower stressor intensity than combat situations such as World War II and the Vietnam War, peacekeeping personnel can also be subjected to stressful situations. During deployment, peacekeeping soldiers may be exposed to potentially traumatic war zone situations, such as shootings, being held hostage, sniper attacks, and the presence of mines (Litz, 1996). In addition, peacekeepers are increasingly providing humanitarian aid and may witness human distress, such as starving, sick, or wounded people. Several studies have demonstrated that peacekeepers also may develop PTSD (Litz, Orsillo, Friedman, Ehlich, \& Batres, 1997; Mehlum \& Weisaeth, 2002; Weisaeth, Aarhaug, Mehlum, \& Larsen, 1993), and such PTSD symptoms may, in turn, burden the partner or other close relatives of the peacekeepers.

Until now, however, little systematic research has been done among family members of veterans who participated in international peacekeeping operations. MacDonald, Chamberlain, Long, and Mirfin (1996) reported on the partners of New Zealand service personnel who had participated in peacekeeping operations and concluded that the period during deployment was very stressful for these partners. This was reflected in decreased well-being, increased psychological distress, and increased daily and work-related hassles during deployment. However, these negative effects were relatively short-lived because after the deployment, substantial improvements were found, with higher levels of 
well-being and lower levels of psychological distress (Mac- Donald et al., 1996). However, MacDonald et al. did not investigate differences in posttraumatic stress reactions between partners of peacekeepers in cases in which the peacekeeper displayed various levels of posttraumatic stress symptoms.

The aim of the present study is to examine whether signs of secondary traumatic stress reactions exist among family members of former peacekeepers. Therefore, we examined differences between family members of peacekeepers with various levels of posttraumatic stress. The whole family system can be affected when one member is traumatized. As mentioned above, most prior studies on secondary traumatic stress focused on partners of traumatized veterans. However, other studies have shown transgenerational effects of trauma among children of certain populations, such as children of Vietnam War veterans and Holocaust survivors (e.g., Epstein, 1982; Rosenheck \& Nathan, 1985). Because peacekeeping soldiers are often young and living at home, their parents may be susceptible to secondary traumatization. In the present study, partners of one subgroup of the peacekeepers and parents of the remaining subgroup of the peacekeepers were investigated.

On the basis of earlier studies (Beckham, Lytle, \& Feldman, 1996; Bramsen et al., 1995; Figley, 1998; Riggs et al., 1998; Solomon et al., 1992), the following hypotheses were formulated. With respect to the partners, we hypothesized that the partners of peacekeepers with higher levels of posttraumatic stress will themselves report more PTSD symptoms, and more sleeping and somatic problems, than partners of peacekeepers with lower levels of posttraumatic stress. In addition, we hypothesized that the partners of peacekeepers with higher levels of posttraumatic stress would appraise the quality of the marital relationship as less favorable and would experience more problems in social contacts than partners of peacekeepers with lower levels of PTSD symptoms. With respect to the parents, we hypothesized that the parents of peacekeepers with higher levels of posttraumatic stress would themselves report more PTSD symptoms, more sleeping and somatic problems, and more problems in social contacts than would parents of peacekeepers with lower levels of posttraumatic stress.

\section{METHOD}

\section{Design and Procedure}

This study, conducted among family members of male Dutch peacekeeping soldiers, was part of a large-scale investigation into the need for aftercare among former peacekeepers (who participated in peacekeeping operations since 1975) and their family members. Of about 8,000 peacekeepers who were sent a questionnaire during the first phase of the study, $43 \%\left(N \_3,481\right)$ returned the completed questionnaire (Dirkzwager, Bramsen, \& Van der Ploeg, 2005). A total of 2,884 peacekeepers agreed to participate in the second phase of the study and received two additional questionnaires, one for themselves and one for their partner or another family member. The present study is based on this second phase. The peacekeepers were asked to give the questionnaire to their partner or another family member (no priority for one particular family member was indicated). In addition to the questionnaire, the family members received a letter informing them about the study. The completed questionnaire could be returned with a prepaid envelope, thereby giving informed consent. Prior to the start of the study, the project was reviewed and approved by the Medical Ethical Committee of the University Hospital Leiden and the Faculty of Medicine, University of Leiden. In accordance with Dutch law, the study protocol included a detailed set of rules and regulations established to protect the privacy of the respondents, which had been approved by the Dutch Data Protection Authority.

\section{Participants}

A total of 1,476 peacekeepers participated (51\% response). Chi-square tests and $t$ tests were used to explore whether those who participated in the second phase of the study differed from those who participated in the first phase only. There was no significant difference between responders and nonresponders of the second phase for level of education, marital status, branch of military service, current PTSD symptoms, sleeping problems, or somatic complaints. Those who also participated in the second phase reported, on average, more potentially traumatic situations during deployment, $t(3$, 481) $\_$3.72, $p \_.01$ and were somewhat older, $t(3,437) \_$8.4, $p \_.01$. From the 1,476 participating 
peacekeepers, 1,040 family members (708 partners and 332 parents) returned the questionnaire; thus, for $70 \%$ of the responding peacekeepers, a family member participated in the study.

On average, the peacekeepers were 32 years old (range $\_19-71$ years, $S D \_9.7$ ), and one third of them were single. Twelve percent of the peacekeepers had completed a higher educational degree (i.e., college or university). Peacekeepers from each branch of the military service were included. More than $60 \%$ were peacekeepers of the Royal Netherlands Army, 30\% served in the Royal Netherlands Navy, and 7\% were peacekeepers serving in the Royal Netherlands Air Force; 76\% had a rank lower than noncommissioned officer. On average, the peacekeepers served 5.7 months abroad (range _ 1-23 months; $S D$ _ 3.9), and the peacekeepers were studied an average of 6.6 years following their deployment (range $\_\_1$ year to 20 years; $S D \_5.6$ ).

Table 1 presents demographic characteristics of the partners and parents of the peacekeepers. Almost all partners are female (99\%), with an average age of 32 years (range _ 17-69 years; SD _ 10.2); $61 \%$ of the partners knew the peacekeeper before the deployment took place. One third of the partners were already living together with the peacekeeper before the deployment, and $91 \%$ of the partners were living with the peacekeeper at the time of the study. About $60 \%$ of the parents who answered the questionnaire were female. The average age of the parents was 54 years (range _ $41-81$ years; $\left.S D \_6.9\right)$. Most of them (88\%) were living with the peacekeeper before the deployment, and more than half were living with the peacekeeper at the time of the study.

About 30\% of the partners were living with a peacekeeper who had served in Lebanon (1979 1985), about 20\% were living with a peacekeeper who served in the former Yugoslavia (1992-1996), and $13 \%$ were living with a peacekeeper who had served in Cambodia (1992-1994). The majority of the parents (67\%) were related to peacekeepers who were stationed in the former Yugoslavia.

\section{Measures}

Questionnaires on PTSD, somatic complaints, sleeping problems, and social support were completed by partners and parents, whereas the questionnaire assessing the quality of the marital relationship was completed by the partners only.

PTSD. The Self-Rating Inventory for PTSD (SRIP) was used to measure current PTSD symptoms of both the peacekeepers and the family members (Hovens et al., 1994). The SRIP consists of 22 items that follow the description of PTSD in the Diagnostic and Statistical Manual of Mental Disorders (Fourth Edition; DSM-IV; American Psychiatric Association, 1994). Sum scores for reexperiencing (6 items), avoidance (9 items), and hyperarousal (7 items) can be derived. Answers are given on a 4-point intensity scale ranging from 1 (not at all) to 4 (very much). All items were written without reference to a specific trauma (e.g., "Ihad recurrent unpleasant memories" instead of "Ihad recurrent unpleasant memories about the deployment”). The SRIP has proved to be reliable and valid (Hovens, Bramsen, \& Van der Ploeg, 2000; Hovens et al., 1994). The test-retest reliability correlation coefficient was .92, and the internal consistency alpha coefficient was .92. The scale correlated significantly with the Clinician Administered PTSD Scale (CAPS), the Mississippi Scale for Combat-Related PTSD, the Minnesota Multiphasic Personality Inventory PTSD subscale, and the Impact of Event Scale. Sensitivity and specificity of the SRIP in relation to the CAPS were found to be very good (sensitivity _85\%; specificity __ 70\%; Hovens et al., 1994).

\section{[ TABLE 1 ]}

In the present study, the total score of the 22 items was used as a measure of current PTSD symptom severity; Cronbach's alpha coefficient for the scale was .94. PTSD diagnosis was determined according to the DSM-IV guidelines: A person had to report a score of quite a bit or a great deal on at least one item of Criterion B (intrusion), at least three items of Criterion C (avoidance), and at least two items of Criterion D (hyperarousal).

It can be assumed, however, that persons not meeting all criteria for a PTSD diagnosis (i.e., those having partial or subthreshold PTSD) can also experience serious problems (e.g., Stein, Walker, Hazen, \& Forde, 1997; Zlotnick, Franklin, \& Zimmerman, 2002) affecting the family members. Furthermore, we were interested in the effect of the degree of PTSD symptoms. Because the operationalization of partial PTSD is still unclear (Mylle \& Maes, 2004), we followed a four-group division according to the DSM-IV. This division was based on the degree of PTSD symptoms of the 
peacekeepers: (a) family members whose peacekeeper met no criteria for PTSD, (b) family members whose peacekeeper met one criterion for PTSD (criterion B, C, or D), (c) family members whose peacekeeper met two criteria for PTSD (criteria B and C; B and D; or C and D), and (d) family members whose peacekeeper met three criteria for PTSD (the full PTSD diagnosis).

Current sleeping and somatic problems. Current sleeping problems and somatic complaints were measured by means of a Dutch adaptation of two scales of the Symptom Checklist - 90 (SCL-90; Arrindell \& Ettema, 1986; Derogatis, 1977). A 5-point Likert scale (1_ not at all; 5 _ very much) was used to measure the severity of sleeping problems and somatic complaints that occurred in the preceding week. Cronbach's alpha for this sample was .84 for sleeping problems and .82 for somatic complaints.

Marital relationship. A Dutch adaptation of the Marital scale of the Maudsley Marital Questionnaire (Crowe, 1978) was used to measure the quality of the marital relationship (Arrindell, Boelens, \& Lambert, 1983; Arrindell, Emmelkamp, \& Bast, 1983). Ten items reflecting the subjective evaluation of the emotional bond with the partner were included. The answering format consisted of a 9-point scale ranging from 0 to 8 . This scale has shown high internal consistency and sufficient testretest reliability and validity (Arrindell, Boelens, \& Lambert, 1983; Arrindell, Emmelkamp, \& Bast, 1983). A total score was computed, with higher scores indicating a higher degree of dissatisfaction with the relationship. In the present study, Cronbach's alpha coefficient for the marital scale was .92. A score of 20 or higher on the marital scale is considered to indicate the existence of a problematic relationship. In his study, Arrindell (1987) found that $6 \%$ of the wives of 64 pairs who were "happily married" had a score of 20 or higher. In addition, he found that the women of 125 couples from a nonclinical population reported a mean score of 10.9 (SD_8.9) on the marital scale.

Current social support. To measure current social support, we used a Dutch adaptation of the Social Support Questionnaire (Revenson, Wollmann, \& Felton, 1983; Tempelaar, De Haes, Van den Heuvel, \& Van Nieuwenhuijzen, 1987; Van Oostrom, Tijhuis, De Haes, Tempelaar, \& Kromhout, 1995). Eight items referring to positive social support in the preceding week and eight items referring to negative social support in the preceding week were included, resulting in two summary scores (i.e., current positive and current negative social support). A 4-point Likert scale was used (1_never; 4 ] often). The reliability of both the positive and negative dimensions was good, and the validity was confirmed (Tempelaar et al., 1987; Van Oostrom et al., 1995). In the present study, Cronbach's alpha coefficients were .83 for positive social support and .77 for negative social support.

Stressful life events. A list of other stressful life events experienced by the couples was used to address the following topics: severe illness or injury of oneself or significant others, death of significant others, decline in financial situation, threat of discharge, serious problems with a family member, problems with the police, and victim of a crime or accident. Respondents were asked whether they had experienced these events during the previous 12 months.

\section{Data Analyses}

The data of partners and parents of former peacekeepers were analyzed separately. To examine differences between partners of peacekeepers with various levels of posttraumatic stress we divided the partners into four groups. This resulted in the following partner groups: (a) 558 partners whose peacekeepers met no criteria for PTSD, (b) 71 partners whose peacekeepers met one criterion for PTSD, (c) 39 partners whose peacekeepers met two criteria for PTSD, and (d) 28 partners whose peacekeepers met all three criteria for PTSD. Because of missing values on the variable regarding PTSD symptoms of the peacekeeper, the total number of partners in the four groups is smaller than 708 ( $N$ [ 696). For parents of former peacekeepers, we followed the same procedure, resulting in the following four groups: (a) 239 parents of peacekeepers who met no criteria for PTSD, (b) 38 parents of peacekeepers who met one criterion for PTSD, (c) 25 parents of peacekeepers who met two criteria for PTSD, and (d) 27 parents of peacekeepers who met three criteria for PTSD. Because of missing values, the total number of parents in the four groups is smaller than 332 ( $\left.N \_329\right)$.

To study overall differences in the outcome measures between family members of peacekeepers with various levels of posttraumatic stress, we performed a multivariate analysis of variance (MANOVA), with the peacekeepers' symptom level as the independent variable and the health problems of the family members, their social support, and the quality of the marital relationship as dependent variables. The multivariate main effect of the degree of peacekeepers' PTSD symptoms was 
tested by means of Wilks's lambda. Bivariate differences were tested by means of analysis of variance with planned comparisons (Helmert contrasts; SPSS, 1997). The following contrasts were examined: Partners of peacekeepers with no PTSD symptoms versus partners of peacekeepers who met one, two, or three criteria for PTSD; partners of peacekeepers who met one criterion for PTSD versus partners of peacekeepers who met two or three criteria for PTSD; and partners of peacekeepers who met two criteria for PTSD versus partners of peacekeepers who met three criteria for PTSD. We used planned comparisons because specific a priori hypotheses were formulated regarding the direction of the differences. The use of planned comparisons also has some advantages over post hoc tests; the test is more powerful and, unlike post hoc tests, not all pairwise comparisons are tested, therefore decreasing the risk of Type Ierrors.

For the partners of peacekeepers, other stressful life events experienced in the previous 12 months were examined as covariates. Only two stressful life events were significantly correlated with partner symptoms and, therefore, included in the analyses: death of a family member or another important person and a decline in financial position. In this way, we were able to examine the effect of the peacekeeper's symptom level after controlling for other stressful life events. For the parents of peacekeepers, the gender of the parent who completed the questionnaire and whether the parent was living with the peacekeeper at the time of the study were included as covariates. A chi-square test was used to compare partners of peacekeepers with and without PTSD symptoms with respect to the existence of a problematic relationship.

\section{RESULTS}

\section{Intercorrelations}

Table 2 presents the Pearson correlations between variables for both the partners and parents of peacekeepers. As can be seen, the variables are highly correlated. The total PTSD score correlated especially highly with the scores of the three separate clusters of PTSD.

\section{Partners of Former Peacekeepers}

Table 3 shows the mean scores for health-related problems, the quality of the marital relationship, and the level of social support of the partners whose peacekeepers reported various levels of posttraumatic stress. The MANOVA showed a significant main effect for the peacekeepers' symptom level (Wilks's _ _.91, $\left.F(24,653) \_2.60, p \_.01\right)$. No significant effects were found for the two covariates: death of a loved one and decline in the financial position.

The Helmert contrasts showed that partners of peacekeepers without posttraumatic stress symptoms reported significantly less PTSD symptoms themselves than partners whose peacekeepers met one, two, or three criteria for PTSD. No significant differences were found between partners of peacekeepers with one, two, or three criteria for PTSD. Partners whose peacekeeper met one, two, or three criteria for PTSD also reported more somatic complaints and sleeping problems than did partners of peacekeepers without PTSD symptoms. With respect to sleeping problems, we found that partners of peacekeepers with the PTSD diagnosis reported significantly more sleeping problems than partners of peacekeepers who met two criteria for PTSD.

With respect to the quality of the marital relationship, all Helmert contrasts were significant. Thus, partners whose peacekeeper met one, two, or three criteria for PTSD appraised their relationship as less favorable than did partners of peacekeepers without PTSD symptoms. Compared with partners whose peacekeeper met one criterion for PTSD, partners of peacekeepers meeting two or three criteria for PTSD evaluated their relationship as less positive. In addition, partners of peacekeepers who fulfilled the criteria for a PTSD diagnosis appraised their relationship as less favorable than partners of peacekeepers who met two criteria for PTSD.

Compared with partners of peacekeepers with no posttraumatic stress symptoms, partners whose peacekeeper met one, two, or three criteria for PTSD reported more negative social support during the week preceding the study. With respect to positive social support, no significant differences were found.

Among all partners of former peacekeepers, 19\% reported a score of 20 or higher on the marital scale (indicating a problematic relationship); $16 \%$ of the partners of peacekeepers with no PTSD symptoms reported a score of 20 or higher on the marital scale. Among partners whose peacekeepers 
met one, two, or three criteria for PTSD, these values were higher; $26 \%$, $24 \%$, and $39 \%$, respectively, $\square^{2}\left(3, N \_666\right) \_11.53, p \_.01$. Thus, compared with partners of peacekeepers without posttraumatic stress, more partners of peacekeepers with PTSD symptoms reported a score indicating a problematic relationship. This score is also much higher when compared with couples who were "happily married"; $6 \%$ of these wives had a score in the range of a problematic relationship (Arrindell, 1987).

\section{Parents of Former Peacekeepers}

Table 4 shows the mean scores for health-related problems and social support of the parents of the peacekeepers. The MANOVA examining differences between parents whose peacekeepers reported various levels of posttraumatic stress was not significant, indicating no main effect for the peacekeepers' symptom level, Wilks's __. $93 ; F(21,308) \_1.06, p \_.39$. The effect of whether the parent was living with the peacekeeper at the time of the study was not significant. The gender of the parent was a significant covariate, Wilks's _ $.88 ; F(7,308) \_5.84, p$ .01 . Analyses showed that mothers reported more PTSD symptoms ( $\left.M \_29.76, S D \_10.55\right) ; t(319)$ 2.67, $p \_.01$, more sleeping problems $\left(M \_5.41, S D \_3.01\right) ; t(319) \_3.66, p \_.01$, and more somatic problems $\left(M \_18.41, S D \_6.27\right)$; $t(319) \_5.80, p \_.01$, than did fathers of the peacekeepers $\left(M \_26.77, S D \_8.16 ; M \_4.26, S D \_2.13 ; M \_14.72, S D \_3.73\right.$, respectively).

\section{[ TABLE 2 ]}

\section{[ TABLE 3 ]}

\section{[ TABLE 4 ]}

\section{DISCUSSION}

The aim of the present study was to examine whether partners and parents of former peacekeepers showed signs of secondary traumatic stress reactions. We found that partners whose peacekeepers showed posttraumatic stress symptoms reported significantly more PTSD symptoms themselves, more somatic problems, more sleeping problems, and more negative social support and also judged the marital relationship as less favorable than did partners of peacekeepers without PTSD symptoms. With respect to the parents, no significant differences were found among parents of peacekeepers with various levels of posttraumatic stress. The intimate nature of the marital relationship and the fact that the partner is usually the main source of support could make the partner more vulnerable for secondary traumatization than extended family members. In addition, the fact that many parents were not living with the peacekeeper at the time of the study (thus, were more distant from the PTSD problems) might have contributed to the difference found between partners and parents. However, within the group of parents, this variable did not have a significant effect.

The results of the present study are consistent with previous studies among partners of other military veteran populations (Bramsen et al., 1995; Riggs et al., 1998; Solomon et al., 1992) and suggest that partners of peacekeeping soldiers with PTSD symptoms also may be subjected to traumatic stress reactions. These findings may indicate secondary traumatization; however, because the data were collected retrospectively by means of self-reported data, other alternative explanations must be considered. For instance, we cannot rule out the possibility that the PTSD symptoms of the partner predated the peacekeeper's PTSD symptoms and hence influenced the peacekeeper's likelihood of developing PTSD symptoms. In addition, when the peacekeeper has PTSD symptoms, the couple is more likely to develop relational problems. However, it can also be hypothesized that in couples with relational problems, the peacekeeper is more susceptible to developing PTSD symptoms following deployment because of a less supportive network. Alternatively, Solomon et al. (1992) suggested that close and prolonged contact with a traumatized veteran may serve as a chronic stressor, which can result in physical and psychiatric distress among the partners of traumatized veterans. In addition, military veterans with PTSD are more inclined to display both physically and emotionally aggressive and hostile behaviors than veterans without PTSD (Beckham, Roodman, et al., 1996; Carroll et al., 1985; Jordan et al., 1992; Matsakis, 1988). Such domestic violence may act as primary 
trauma for the partners. Finally, the assortative mating hypothesis may provide an alternative explanation, whereby persons with similar characteristics (e.g., depressive tendencies) tend to choose each other as mates (Negri, Melicia, Zuliani, \& Smeraldi, 1979; Solomon et al., 1992).

Before discussing the meaning and implications of the results of the present study, some limitations must be considered. First, among the peacekeepers who were approached, approximately one third of the family members responded. It is possible, therefore, that a selection has occurred, which may limit the generalizability of the results. For instance, peacekeepers who perceived their family members to be more supportive may have been more inclined to participate, leaving those with dysfunctional relationships underrepresented. In that case the results of the present study would be a conservative estimate of the effects of being a peacekeeper's family member. Because peacekeepers could participate anonymously during the first phase of the study, no information about the nonresponders was available.

Second, the Self-Rating Inventory for PTSD measures current symptoms of PTSD without making reference to a specific trauma. Therefore, it remains unclear whether the family members of peacekeepers suffer from posttraumatic stress as a result of the PTSD symptoms of the peacekeeper or as a result of, for instance, another trauma experienced by the family members themselves or other life events experienced by the couple. The analyses of covariance, however, showed that other stressful life events (i.e., the death of a loved one and a decline in the financial position) did not eliminate the effect of the level of PTSD symptoms of the peacekeeper. However, asking people to link their current psychological symptoms to a specific stressor may also result in methodological problems. For instance, Green (1993) has argued that asking about stressors and symptoms simultaneously, particularly in the format where participants must make dynamic links between the two, is likely to yield data that are not generalizable. Although the approach used in the present study limits our possibilities of interpreting the results as secondary traumatization, the results do show that, compared with partners of peacekeepers with no PTSD symptoms, partners of peacekeepers with PTSD symptoms reported significantly more PTSD symptoms of themselves. This suggests that posttraumatic stress reactions of the partners and the peacekeepers are related and not independent of each other.

Third, all the peacekeepers in the present study were male. Therefore, our results concerning potential secondary traumatic stress among partners of peacekeepers are limited to female partners. It will be interesting to examine secondary traumatic stress among both female and male partners of peacekeepers, as stress transmission within couples may vary by gender.

Despite these limitations, we believe the present study has important strengths. First, to our knowledge, this study is the first to focus on possible secondary traumatic stress reactions among family members of peacekeeping personnel and to focus on both partners and parents. In addition, the previous studies of Jordan et al. (1992), Riggs et al. (1998), and Solomon et al. (1992) examining secondary traumatization in families of combat veterans did not investigate the occurrence of PTSD symptoms among the partners. Therefore, the present study may add valuable and unique information concerning traumatic stress reactions in this particular group. Another advantage of the present study is that information was gathered from both the family members and the former peacekeepers. The family members provided information concerning their health status, social contacts, and the marital relationship. The degree of PTSD symptoms of the peacekeepers was based on information from the peacekeepers themselves.

It is clear that having a partner with PTSD symptoms is distressing and affects the quality of the relationship. The present study showed that $25 \%$ to $39 \%$ of the partners of peacekeepers with PTSD symptoms scored in the range of a clinically problematic relationship. This is much higher when compared with couples who were happily married (Arrindell, 1987). Partners are usually the main source of support. However, PTSD symptoms of the peacekeepers may put such a strain on the marital relationship that partners may find it difficult to provide the type of support that may be beneficial for the veterans' adjustment (Shehan, 1987).

It has been argued that couples with one partner suffering from PTSD symptoms may become socially isolated (Gilbert, 1998). In the present study, partners of peacekeepers with PTSD symptoms reported more negative social support than did partners of peacekeepers without PTSD symptoms. This means that at a time when the partners are facing major problems and the need for supportive social contacts may be high, the partners also may have to deal with more negative social contacts. 
Gilbert (1998) argues that social isolation may result from factors from within and outside the couple: For example, the PTSD problems of the primary traumatized partner may prevent family members from seeing other people; the secondary traumatized partner may think that others cannot understand what they are going through; or the social network surrounding the couple may not be willing to listen to their problems.

The results of the present study suggest that living with a peacekeeper with PTSD symptoms may result in problems of the partners in a variety of aspects of their daily functioning. In trying to prevent such problems, it may be meaningful to involve the partners of peacekeepers in all phases of the deployment. For instance, during the preparation of the deployment by information distribution; during the deployment period by self-support groups, a news bulletin providing information to the families, or facilities for maintaining contact with the deployed peacekeeper; and after the deployment by including the partners in the debriefing and aftercare. Educational efforts aimed at strengthening families’ coping skills, such as those suggested by Peebles-Kleiger and Kleiger (1994), may also be effective. In addition, families could be educated about self-help coping skills; for example, McCubbin and Figley (1983) have described ways in which family members can improve their own chances of coping successfully with a crisis and feel emotionally supported by each other. Involving and informing family members of peacekeepers can help them better prepare for the deployment period and potential adjustment problems of the peacekeeper following deployment. In this way they may better understand what is happening and may sooner recognize adjustment problems following return, both of the peacekeeper and of themselves. However, further research is needed to determine whether interventions, such as involving partners of peacekeepers in the phases of deployment, are effective in preventing secondary traumatic stress reactions.

The implication of this study for clinicians is that living with a person who has PTSD symptoms has an important effect on the partners. Clinicians must be alert that supporting and caring for a traumatized person may drain the resources of the partner and may eventually lead to (secondary) traumatic stress reactions. Thus, following a systemic approach in the treatment of persons with PTSD may be most appropriate (Figley, 1988, 1993; Hogancamp \& Figley, 1983; Nelson \& Wright, 1996; Stanton \& Figley, 1978). A study among veterans of Operation Desert Storm and their partners showed that a family psychosocial approach resulted in improvements among both veterans and their partners. Partners who participated in the treatment showed an overall decrease in psychological symptomatology (Ford et al., 1993). Such a systemic approach may prevent secondary traumatic stress reactions among the partner and may help to improve the couple's interactions, communication and social support.

Considering the number of ongoing peacekeeping operations and the increase in the number of peacekeeping and peace-enforcement operations since 1990, an increasing number of family members of peacekeepers will have to deal with stressors of the deployment and adjustment problems of the peacekeeper following deployment. The present study suggests that in trying to support and care for a traumatized peacekeeper the partner's resources may become overwhelmed, and this may result in (secondary) traumatic stress reactions.

Future research should focus on factors that bring about the process of secondary traumatic stress reactions because it is not yet clear which family members are most vulnerable to develop secondary traumatization. Factors associated with both the peacekeeper and the partner or the environment of the couple may be important. For instance, factors such as social support surrounding the couple, the coping style of the partner and/or the family may be important in decreasing the risk for secondary traumatic stress reactions. 
A.J.E. Dirkzwager, I. Bramsen, H. Ader, H.M. van der Ploeg

Secondary traumatization in partners and parents of Dutch peacekeeping soldiers.

Journal of Family Psychology: jrg. 19, 2005, nr. 2, p. 217-226

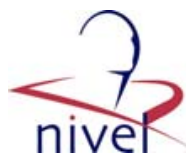

\section{TABLES}

Table 1

Demographic Characteristics of Family Members of Former Peacekeepers

\begin{tabular}{|c|c|c|c|c|}
\hline \multirow[b]{2}{*}{ Characteristics } & \multicolumn{2}{|c|}{$\begin{array}{c}\text { Partners } \\
(N=708)\end{array}$} & \multicolumn{2}{|c|}{$\begin{array}{c}\text { Parents } \\
(N=332)\end{array}$} \\
\hline & $n$ & $\%$ & $n$ & $\%$ \\
\hline \multicolumn{5}{|l|}{ Sex } \\
\hline Male & 9 & 1 & 126 & 38 \\
\hline Female & 698 & 99 & 206 & 62 \\
\hline \multicolumn{5}{|l|}{ Education } \\
\hline Low (elementary school) & 130 & 18 & 135 & 41 \\
\hline Intermediate (high school) & 394 & 56 & 122 & 37 \\
\hline High (college, university) & 125 & 18 & 42 & 13 \\
\hline Other & 54 & 8 & 30 & 9 \\
\hline Mean age in years & $32.3^{\mathrm{a}}$ & & $53.8^{\mathrm{a}}$ & \\
\hline Living with peacekeeper before deployment took place & 227 & 32 & 293 & 88 \\
\hline Living with peacekeeper at time of study (1996) & 646 & 91 & 178 & 54 \\
\hline Knew peacekeeper before deployment & 428 & 61 & & \\
\hline \multicolumn{5}{|l|}{ Peacekeeping operation of veteran } \\
\hline Former Yugoslavia & 152 & 23 & 218 & 67 \\
\hline Lebanon & 219 & 32 & 34 & 10 \\
\hline Cambodia & 85 & 13 & 30 & 9 \\
\hline Persian Gulf & 73 & 11 & 12 & 4 \\
\hline Other & 148 & 22 & 33 & 10 \\
\hline
\end{tabular}

Table 2

Intercorrelations Between Variables for Partners and for Parents of Peacekeepers

\begin{tabular}{|c|c|c|c|c|c|c|c|c|c|}
\hline Variable & 1 & 2 & 3 & 4 & 5 & 6 & 7 & 8 & 9 \\
\hline 1. PTSD symptom severity & - & $.90 * *$ & $.94 * *$ & $.92 * *$ & $.49 * *$ & $.54 * *$ & $-.17 * *$ & $.37 * *$ & $.26^{* *}$ \\
\hline 2. PTSD Intrusion & $.91 * *$ & - & $.81 * *$ & $.73^{* *} *$ & $.37 * *$ & $.44^{* *}$ & $-.12 * *$ & $.28 * *$ & $.20 * *$ \\
\hline 3. PTSD Avoidance & $.96 * *$ & $.83 * *$ & - & $.77 * *$ & $.39 * *$ & $.49 * *$ & $-.19 * *$ & $.36 * *$ & $.26 * *$ \\
\hline 4. PTSD Hyperarousal & $.93 * *$ & $.78 * *$ & $.83 * *$ & - & $.58 * *$ & $.54 * *$ & $-.15 * *$ & $.36 * *$ & $.26 * *$ \\
\hline 5. Sleeping problems & $.48 * *$ & $.34 * *$ & $.42 * *$ & $.56^{* * *}$ & - & $.58 * *$ & $-.13 * *$ & $.32 * *$ & $.33 * *$ \\
\hline 6. Somatic problems & $.43 * *$ & $.29 * *$ & $.40 * *$ & $.48 * *$ & $.70 * *$ & - & $-.16 * *$ & $.39 * *$ & $.26 * *$ \\
\hline 7. Positive social support & $-.27 * *$ & $-.22 * *$ & $-.25 * *$ & $-.28 * *$ & $-.17 * *$ & $-.21 * *$ & - & $-.28 * *$ & $-.39 * *$ \\
\hline 8. Negative social support & $.34^{* *}$ & $.24 * *$ & $.35^{* *}$ & $.37 * *$ & $.25 * *$ & $.29 * *$ & $-.32 * *$ & - & $.36^{* * *}$ \\
\hline 9. Quality of marital relationship & & & & & & & & & - \\
\hline
\end{tabular}

Note. Values above the diagonal are the Pearson correlations for the partners of the peacekeepers. Values below the diagonal are the Pearson correlations for the parents of the peacekeepers. PTSD = posttraumatic stress disorder.

$* * p<.01$. 
A.J.E. Dirkzwager, I. Bramsen, H. Ader, H.M. van der Ploeg

Secondary traumatization in partners and parents of Dutch peacekeeping soldiers.

Journal of Family Psychology: jrg. 19, 2005, nr. 2, p. 217-226

Table 3

Comparison of Partners of Peacekeepers with Zero, One, Two, and Three Criteria for Posttraumatic Stress Disorder (PTSD)

\begin{tabular}{|c|c|c|c|c|c|c|c|c|c|c|c|}
\hline \multirow[b]{2}{*}{ Variable } & \multicolumn{2}{|c|}{$\begin{array}{l}\text { Peacekeeper } \\
\text { with zero } \\
\text { criteria for } \\
\text { PTSD } \\
(n=558)\end{array}$} & \multicolumn{2}{|c|}{$\begin{array}{l}\text { Peacekeeper } \\
\text { with one } \\
\text { criterion for } \\
\text { PTSD } \\
(n=71)\end{array}$} & \multicolumn{2}{|c|}{$\begin{array}{c}\text { Peacekeeper } \\
\text { with two } \\
\text { criteria for } \\
\text { PTSD } \\
(n=39) \\
\end{array}$} & \multicolumn{2}{|c|}{$\begin{array}{l}\text { Peacekeeper } \\
\text { with three } \\
\text { criteria for } \\
\text { PTSD } \\
(n=28)\end{array}$} & \multicolumn{2}{|c|}{ Helmert contrasts } & \multirow[b]{2}{*}{$p$} \\
\hline & $M$ & $S D$ & $M$ & $S D$ & $M$ & $S D$ & $M$ & $S D$ & & & \\
\hline \multicolumn{12}{|l|}{ Health-related problems of partner } \\
\hline PTSD total symptom severity & 26.7 & 7.9 & 29.4 & 8.6 & 29.8 & 10.6 & 32.0 & 7.3 & Level 1 ver & Levels $2-4$ & $<.01$ \\
\hline PTSD Intrusion & 6.8 & 2.2 & 7.3 & 2.3 & 7.7 & 2.9 & 7.9 & 2.1 & Level 1 ver & Levels $2-4$ & $<.01$ \\
\hline PTSD Avoidar & 10.8 & 3.3 & 11.9 & 3.4 & 12.1 & 4.6 & 12.9 & 3.5 & evel 1 ver & Levels $2-4$ & $<.01$ \\
\hline PTSD Hyperarousal & 9.1 & 3.1 & 10.2 & 3.8 & 10.0 & 3.6 & 11.2 & 2.7 & Level 1 ver & Levels $2-4$ & $<.01$ \\
\hline Sleeping problems (SCL-90) & 4.3 & 2.2 & 4.9 & 2.9 & 4.4 & 2.1 & 6.0 & 2.9 & $\begin{array}{l}\text { Level } 1 \text { vers } \\
\text { Level } 3 \text { vers }\end{array}$ & $\begin{array}{l}\text { Levels 2-4 } \\
\text { Level } 4\end{array}$ & $\begin{array}{l}<.01 \\
<.01\end{array}$ \\
\hline $\begin{array}{l}\text { Somatic problems (SCL-90) } \\
\text { ppraisal of marital relationship }\end{array}$ & 16.3 & 4.9 & 18.4 & 6.0 & 18.4 & 6.9 & 19.6 & 5.2 & Level 1 vers & Levels $2-4$ & $<.01$ \\
\hline Quality of marital relationship & 10.4 & 9.5 & 13.5 & 12.4 & 14.4 & 12.1 & 20.7 & 22.9 & $\begin{array}{l}\text { Level } 1 \text { vers } \\
\text { Level } 2 \text { vers } \\
\text { Level } 3 \text { vers }\end{array}$ & $\begin{array}{l}\text { Levels } 2-4 \\
\text { Levels 3-4 } \\
\text { Levels } 4\end{array}$ & $\begin{array}{l}<.01 \\
<.05 \\
<.05\end{array}$ \\
\hline $\begin{array}{l}\text { Current social support of partner } \\
\text { Positive social support }\end{array}$ & 23.5 & 3.8 & 23.2 & 3.9 & 23.6 & 4.3 & 23.8 & 4.9 & & & \\
\hline Negative social support & 10.8 & 2.7 & 11.8 & 3.7 & 12.0 & 4.1 & 12.9 & 4.0 & Level 1 ve & Levels 2-4 & $<.01$ \\
\hline \multicolumn{12}{|c|}{$\begin{array}{l}\text { Note. SCL-90 = Symptom Checklist Revised-90. Higher mean scores correspond to a higher degree of health-related problems, a higher } \\
\text { degree of dissatisfaction with the relationship, a higher degree of positive social support, and a higher degree of negative social support, } \\
\text { respectively. Level } 1 \text { versus Level } 2-4 \text { means: The mean score of partners of peacekeepers who met zero criteria for PTSD differs } \\
\text { significantly from the mean score of the partners of peacekeepers who met one, two, or three criteria for PTSD. Level } 2 \text { versus levels } 3-4 \\
\text { means: The mean score of partners of peacekeepers who met one criterion for PTSD differs significantly from the mean score of the } \\
\text { partners of peacekeepers who met two or three criteria for PTSD. Level } 3 \text { versus Level } 4 \text { means: The mean score of the partners of } \\
\text { peacekeepers who met two criteria for PTSD differs significantly from the mean score of the partners of peacekeepers who met three } \\
\text { criteria for PTSD }\end{array}$} \\
\hline \multicolumn{12}{|c|}{$\begin{array}{l}\text { Comparison of Parents of Peacekeepers with Zero, One, Two, and Three Criteria for Posttraumatic Stress Disorder } \\
\text { (PTSD) }\end{array}$} \\
\hline \multirow[b]{2}{*}{ Variable } & \multicolumn{3}{|c|}{$\begin{array}{l}\text { Peacekeeper } \\
\text { with zero } \\
\text { criteria for } \\
\text { PTSD } \\
(n=239)\end{array}$} & & \multicolumn{3}{|c|}{$\begin{array}{c}\text { Peacekeeper with } \\
\text { one criterion for } \\
\text { PTSD } \\
(n=38)\end{array}$} & \multicolumn{2}{|c|}{$\begin{array}{l}\text { Peacekeeper with } \\
\text { two criteria for } \\
\text { PTSD } \\
(n=25)\end{array}$} & \multicolumn{2}{|c|}{$\begin{array}{l}\text { Peacekeeper } \\
\text { with three } \\
\text { criteria for } \\
\text { PTSD } \\
(n=27)\end{array}$} \\
\hline & & $M$ & $S D$ & & $M$ & & $D$ & $M$ & $S D$ & $M$ & $S D$ \\
\hline \multicolumn{12}{|l|}{ Health-related problems of parent } \\
\hline PTSI & & 7.8 & 8.9 & & 31.1 & & 4.5 & 31.0 & 11.3 & 30.8 & \\
\hline PTSD I & & & & & & & & & & & \\
\hline PTSD $A$ & & & 4 & & 12.9 & & б. & 12 & & 12 & 4.4 \\
\hline & & & & & 10.5 & & & 10 & 4 & 10.3 & 3.3 \\
\hline Sleep & & & & & & & & & & & \\
\hline Somatic problems (SCL-90) & & 6.8 & 5.4 & & 17.8 & & 7.8 & 17.1 & 6.9 & 17.4 & 4.5 \\
\hline \multicolumn{12}{|l|}{ Current social support of parent } \\
\hline Positive soci & & & 3. & & 21.3 & & & 23.0 & & 22.1 & \\
\hline Negative social support & & & 2.7 & & 11.3 & & 2.8 & 10.9 & 2.2 & 11.6 & 2.3 \\
\hline
\end{tabular}

Note. $\quad$ SCL-90 $=$ Symptom Checklist Revised-90. The multivariate analysis of variance for health-related problems and social support of the parents was not significant.

\section{REFERENCES}

1. American Psychiatric Association. (1994). Diagnostic and statistical manual of mental disorders (4th ed.). Washington, DC: Author.

2. Arrindell, W. A. (1987). Marital conflict and agoraphobia: Fact or fantasy? Delft, the Netherlands: Eburon Press.

3. Arrindell, W. A., Boelens, W., \& Lambert, H. (1983). On the psychometric properties of the Maudsley Marital Questionnaire (MMQ): Evaluation of self-ratings in distressed and 'normal' volunteer couples based on the Dutch version. Personality and Individual Differences, 4, 293-306.

4. Arrindell, W. A., Emmelkamp, P. M. G., \& Bast, S. (1983). The Maudsley Marital Questionnaire (MMQ): A further step towards its validation. Personality and Individual Differences, 4, 457- 464.

5. Arrindell, W. A., \& Ettema, J. H. M. (1986). SCL-90. Handleiding bij een multidimensionele psychopathologie-indicator [SCL-90: Manual of a multidimensional psychopathology indicator]. Lisse, the Netherlands: Swets \& Zeitlinger.

6. Beckham, J. C., Lytle, B. L., \& Feldman, M. E. (1996). Caregiver burden in partners of Vietnam War veterans with posttraumatic stress disorder. Journal of Consulting and Clinical Psychology, 64, 1068-1072. 
A.J.E. Dirkzwager, I. Bramsen, H. Ader, H.M. van der Ploeg

Secondary traumatization in partners and parents of Dutch peacekeeping soldiers.

Journal of Family Psychology: jrg. 19, 2005, nr. 2, p. 217-226

7. Beckham, J. C., Roodman, A. A., Barefoot, J. C., Haney, T. L., Helms, M. J., Fairbank, J. A., et al. (1996). Interpersonal and self-reported hostility among combat veterans with and without posttraumatic stress disorder. Journal of Traumatic Stress, 9, 335-342.

8. Bramsen, I., Klaarenbeek, M. T. A., \& Van der Ploeg, H. M. (1995). Leven met militaire oorlogsgetroffenen: De partners van BNMO-leden in beeld gebracht [Living with military war victims: A picture of spouses of BNMO members]. In H. M. van der Ploeg \& J. M. P. Weerts (Eds.), Veteranen in Nederland. Onderzoeknaar de gevolgen van oorlogservaringen - Tweede Wereldoorlog - Politionele Acties — Korea (pp. 147-164). Lisse, the Netherlands: Swets \& Zeitlinger.

9. Bramsen, I., Van der Ploeg, H. M., \& Twisk, J. W. R. (2002). Secondary traumatization in Dutch couples of World War II survivors. Journal of Consulting and Clinical Psychology, 70, 241-245.

10. Carroll, E. M., Rueger, D. B., Foy, D. W., \& Donahoe, C. P. (1985). Vietnam combat veterans with posttraumatic stress disorder: Analysis of marital and cohabitating adjustment. Journal of Abnormal Psychology, 94, 329-337.

11. Crowe, M. J. (1978). Conjoint marital therapy: A controlled outcome study. Psychological Medicine, 8, 623-636.

12. Derogatis, L. R. (1977). SCL-90: Administration, scoring and procedures manual-I for the $R$ (evised) version. Baltimore, MD: Johns Hopkins University School of Medicine, Clinical Psychometrics Research Unit.

13. Dirkzwager, A. J. E., Bramsen, I., \& Van der Ploeg, H. M. (2005). Factors associated with posttraumatic stress among peacekeeping soldiers. Anxiety, Stress, and Coping, 18(1), 37-57.

14. Egge, B., Mortensen, M. S., \& Weisaeth, L. (1996). Armed conflicts. Soldiers for peace: Ordeals and stress. In Y. Danieli, N. S. Rodley, \& L. Weisaeth (Eds.), International responses to traumatic stress. Humanitarian, human rights, justice, peace and development contributions, collaborative actions, and future initiatives (pp. 257-282). New York: Baywood.

15. Epstein, A. W. (1982). Mental phenomena across generations: The Holocaust. Journal of the American Academy of Psychoanalysis, 10, 565-570.

16. Figley, C. R. (1988). A five-phase treatment of post-traumatic stress disorder in families. Journal of Traumatic Stress, 1, 127- 141.

17. Figley, C. R. (1993). Coping with stressors on the home front. Journal of Social Issues, 49(4), 5171.

18. Figley, C. R. (1998). Burnout as systemic traumatic stress. A model for helping traumatized family members. In C. R. Figley (Ed.), Burnout in families. The systemic costs of caring (pp. 15-28). New York: CRC Press.

19. Ford, J. D., Shaw, D., Sennhauser, S., Greaves, D., Thacker, B., Chandler, P., et al. (1993). Psychosocial debriefing after operation Desert Storm: Marital and family assessment and intervention. Journal of Social Issues, 49(4), 73-102.

20. Gilbert, K. (1998). Understanding the secondary traumatic stress of spouses. In C. R. Figley (Ed.), Burnout in families: The systemic costs of caring (pp. 47-74). New York: CRC Press.

21. Green, B. L. (1993). Identifying survivors at risk: Trauma and stressors across events. In J. P. Wilson \& B. Raphael (Eds.), International handbookof traumatic stress syndromes (pp. 135-143). New York: Plenum Press.

22. Hogancamp, V., \& Figley, C. R. (1983). War: Bringing the battle home. In C. R. Figley \& H. I. McCubbin (Eds.), Stress and the family: Volume II. Coping with catastrophe (pp. 148-165). New York: Brunner/Mazel.

23. Hovens, J. E., Bramsen, I., \& Van der Ploeg, H. M. (2000). Zelfinventarisatielijst Posttraumatische Stressstoornis (ZIL): Handleiding [Self-Rating Inventory for PTSD: Manual]. Lisse, the Netherlands: Swets \& Zeitlinger.

24. Hovens, J. E., Van der Ploeg, H. M., Bramsen, I., Klaarenbeek, M. T. A., Schreuder, J. N., \& Rivero, V. V. (1994). The development of the self-rating inventory for posttraumatic stress disorder. Acta Psychiatrica Scandinavica, 90, 172-183.

25. Jordan, B. K., Marmar, C. R., Fairbank, J. A., Schlenger, W. E., Kulka, R. A., Hough, R. L., et al. (1992). Problems in families of male Vietnam veterans with posttraumatic stress disorder. Journal of Consulting and Clinical Psychology, 60, 916-926.

26. Litz, B. T. (1996). The psychological demands of peacekeeping for military personnel. Clinical Quarterly, 6(1), 1-8.

27. Litz, B. T., Orsillo, S. M., Friedman, M., Ehlich, P., \& Batres, A. (1997). Posttraumatic stress disorder associated with peacekeeping duty in Somalia for U.S. military personnel. American Journal of Psychiatry, 154(2), 178-184. 
A.J.E. Dirkzwager, I. Bramsen, H. Ader, H.M. van der Ploeg

Secondary traumatization in partners and parents of Dutch peacekeeping soldiers.

Journal of Family Psychology: jrg. 19, 2005, nr. 2, p. 217-226

28. MacDonald, C., Chamberlain, K., Long, N., \& Mirfin, K. (1996). Psychological effects of peacekeeping deployments on the partners of service personnel. Palmerston North, New Zealand: Massey University, Department of Psychology.

29. Maloney, L. J. (1988). Post-traumatic stresses on women partners of Vietnam veterans. Smith College Studies in Social Work, 58(2), 122-143.

30. Matsakis, A. (1988). Vietnam wives. Washington, DC: Woodbine House.

31. McCubbin, H., \& Figley, C. R. (1983). Bridging normative and catastrophic family stress. In C. R. Figley \& $\mathrm{H}$. McCubbin (Eds.), Stress and the family: Volume I. Coping with normative transitions (pp. 218-228). New York: Brunner/Mazel.

32. Mehlum, L., \& Weisaeth, L. (2002). Predictors of posttraumatic stress reactions in Norwegian U.N. peacekeepers 7 years after service. Journal of Traumatic Stress, 15(1), 17-26.

33. Mylle, J., \& Maes, M. (2004). Partial posttraumatic stress disorder revisited. Journal of Affective Disorders, 78, 37-48.

34. Negri, F., Melicia, A. M., Zuliani, R., \& Smeraldi, E. (1979). Assortative mating and affective disorders. Journal of Affective Disorders, 1, 247-253.

35. Nelson, B. S., \& Wright, D. W. (1996). Understanding and treating post-traumatic stress disorder symptoms in female partners of veterans with PTSD. Journal of Marital and Family Therapy, 22, 455-467.

36. Peebles-Kleiger, M. J., \& Kleiger, J. H. (1994). Re-integration stress for Desert Storm families: Wartime deployments and family trauma. Journal of Traumatic Stress, 7(2), 173-194.

37. Revenson, T. A., Wollmann, C. A., \& Felton, B. J. (1983). Social support as stress buffers for adult cancer patients. Psychosomatic Medicine, 45, 321-331.

38. Riggs, D. S., Byrne, C. A., Weathers, F. W., \& Litz, B. T. (1998). The quality of the intimate relationships of male Vietnam veterans: Problems associated with posttraumatic stress disorder. Journal of Traumatic Stress, 11(1), 87-101.

39. Roberts, W. R., Gearing, M. L., Robinowitz, R., Dolan, M. P., \& Patterson, E. T. (1982). Interpersonal problems of Vietnam combat veterans with symptoms of posttraumatic stress disorder. Journal of Abnormal Psychology, 91, 444-450.

40. Rosenheck, R., \& Nathan, P. (1985). Secondary traumatization in children of Vietnam veterans. Hospital and Community Psychiatry, 36, 538-539.

41. Shehan, C. L. (1987). Spouse support and Vietnam veterans' adjustment to post-traumatic stress disorder. Family Relations, 36, 55-60.

42. Solomon, Z., Waysman, M., Levy, G., Fried, B., Mikulincer, M., Benbenishty, R., et al. (1992). From front line to home front: A study of secondary traumatization. Family Process, 31, 289-302.

43. SPSS. (1997). SPSS advanced statistics 7.5. Chicago: SPSS.

44. Stanton, M. D., \& Figley, C. R. (1978). Treating the Vietnam veteran within the family system. In C. R. Figley (Ed.), Stress disorders among Vietnam veterans: Theory, research and treatment (pp. 281-290). New York: Brunner/Mazel.

45. Stein, M. B., Walker, J. R., Hazen, A. L., \& Forde, D. R. (1997). Full and partial posttraumatic stress disorder: Findings from a community survey. American Journal of Psychiatry, 154, 11141119.

46. Tempelaar, R., De Haes, J. C. J. M., Van den Heuvel, W. J. A., \& Van Nieuwenhuijzen, M. G. (1987). Een meetinstrument voor positieve en negatieve sociale ervaringen van (kanker-) patienten [A measurement instrument for positive and negative social experiences of (cancer-) patients]. Tijdschrift voor Sociale Gezondheidszorg, 65(20), 648-653.

47. Van Oostrom, M. A., Tijhuis, M. A. R., De Haes, J. C. J. M., Tempelaar, R., \& Kromhout, D. (1995). A measurement of social support in epidemiological research: The social experiences checklist tested in a general population in the Netherlands. Journal of Epidemiology and Community Health, 49, 518-524.

48. Weisaeth, L., Aarhaug, P., Mehlum, L., \& Larsen, S. (1993). The UNIFIL study: Positive and negative consequences of service in UNIFIL contingents I-XXVI. Report Part I. Results and recommendations. Oslo, Norway: Norwegian Defence Command Headquarters.

49. Zlotnick, C., Franklin, C. L., \& Zimmerman, M. (2002). Does "subthreshold" posttraumatic stress disorder have any clinical relevance? Comprehensive Psychiatry, 43, 413-419. 